\title{
Factors Affecting the Adoption of GIS Systems in the Public Sector in Saudi Arabia and Their Impact on Organizational Performance
}

\author{
Ahmad Alzighaibi*, Masoud Mohammadian, Majharul Talukder \\ Information Systems \& Accounting, Faculty of Business, Government \& Law, University of Canberra, Canberra, \\ Australia \\ Email: "Ahmad.alzighaibi@canberra.edu.au, Masoud.Mohammadian@canberra.edu.au, \\ Majharul.Talukder@canberra.edu.au
}

Received 20 May 2016; accepted 18 June 2016; published 21 June 2016

Copyright (C) 2016 by authors and Scientific Research Publishing Inc.

This work is licensed under the Creative Commons Attribution International License (CC BY).

http://creativecommons.org/licenses/by/4.0/

(c) (i) Open Access

\section{Abstract}

This study investigates the adoption of the new phenomenon of Geographic Information Systems (GIS) in an organizational context in an emerging economy, namely Saudi Arabia. It explores the determinants of employees' perceptions of GIS, their actual usage and expected outcomes when they use it. A model was developed for this study based on relevant theories and existing literature. In total 221 responses were collected from the Ministry of Water and Electricity (MOWE) in Saudi Arabia using a structured survey questionnaire. Several statistical techniques were applied to the data collected. Results show that factors having the most significant impact on employees' perceptions of GIS are managerial support, IT expertise and exposure to GIS. However, some factors did not have any significant impact on employees' perceptions, these being GIS training and incentives. It also emerges that attitude to GIS has an impact on and relationship with the actual usage of GIS. In the outcomes of GIS adoption, results indicate that its usage influences enhanced risk management and better customer relationships. However, no significant relationship was found that led to more efficient decision-making and saving of costs. This paper also highlights implications and discusses the limitations and suggestions for future research.

\section{Keywords}

GIS Training, Managerial Support, Incentives, GIS Adoption, Saudi Arabia, GIS Usage

\footnotetext{
${ }^{*}$ Corresponding author.
}

How to cite this paper: Alzighaibi, A., Mohammadian, M. and Talukder, M. (2016) Factors Affecting the Adoption of GIS Systems in the Public Sector in Saudi Arabia and Their Impact on Organizational Performance. Journal of Geographic Information System, 8, 396-411. http://dx.doi.org/10.4236/igis.2016.83034 


\section{Introduction}

Geographic Information System (GIS) works by integrating hardware, software, and data to capture geographic data and manage them for analysis, and then displaying the finalized geographic information for users to access. It helps users to easily and quickly understand the data and make a decision [1]. The term "Geographic Information Systems Science" has been used for twenty years internationally. This science has many characteristics and employs various intellectual and technical strategies [2]. Geographic Information System is an important science and it is used in three different contexts or classifications as follows: 1) a Geographic Information System "tool"; 2) a Geographic Information System "application"; and 3) a Geographic Information System "science” [2].

There are six components of GIS, the first and most important being the overarching network. The network is a critical aspect of GIS as data and digital information cannot be shared or communicated except through the network. The second component of GIS is the user's hardware, which consists of devices that execute GIS operations [3]. The third component part of GIS is the software. GIS vendors such as the Environmental Systems Research Institute provide packages that can be purchased by organizations. These packages offered by different GIS vendors have varied applications, level of complexity and data size. The fourth component is the database where all information is saved for a future decision or to solve a problem. The fifth component comprises procedures that manage the GIS and keep it within budget constraints, and as accurate as possible so it can satisfy users. The sixth component concerns people, i.e. the users of the GIS and those who provide and update all the digital data on the GIS database so that it is more efficient and effective [3].

There are many benefits of using GIS. These benefits are for all types of organizations and industries whether they are small, medium or large. There are five classifications that these benefits come under, namely saving costs and increasing the organizational efficiency, better decision-making, communication enhancement, more efficient recordkeeping and management of geographical variables [4]. GIS can be merged with any organization's information system framework [1]. Furthermore, GIS is used to store, control and retrieve datasets. It is employed in many applications in many different areas. In GIS a dataset is called a layer, which can refer to roads, seas, buildings, etc. Each layer is stored in a specific location with coordinates in the GIS [5]. Layers that have the same geographical coordinates are linked to each other in the GIS. This relationship, which is referred to as spatial joins between datasets, can help in analyzing the data and making decisions. An example of making decisions can be allocating roads that are close to a certain river. These roads can be allocated by using some queries in the GIS, and help determine roads that may be affected by floods [5].

Another study was conducted in France to reduce the risks of floods/streaming by presenting a framework to manage constraints [6]. Another way that GIS queries can help in decision-making is when infectious diseases can be spread, decisions are vital regarding knowing how long it takes these diseases to reach certain areas and subsequently avoid them [7]. It can also allocate earthquake emergency shelters, which will reduce the amount of damage and injury [8]. An analysis done in South Korea presented a model that can help estimate the amount of forest fire caused by humans. This also can affect the decisions and actions that could be taken to reduce the spread of fire and reduce damage and injuries [9]. GIS was also utilized in Northern Ireland for allocating areas with certain population subgroups according to their religion. The government can employ GIS in helping with development of policies and decisions and manage residential segregation [10]. GIS can also assist in planning for any future climate conditions in rural areas and how to prepare a strategy or strategies in response [11].

There are some general GIS studies that have been conducted in Saudi Arabia. One of these studies is the study by Al-Ramadan (1993) whose main focus was to examine the validity of their hypothesis, which included the highly centralised government in Saudi Arabia may have a much more organized GIS adoption than those governments that are less centralized [12]. Another study by Abdulaal (2009) has provided a general framework for enterprise GIS for Saudi municipalities. This framework includes three main factors, which are business functions, tasks and data requirements [13]. A study by Koshak suggests that during Hajj in Makkah, it is better to use Web-based GIS to manage traffic plan to facilitate easier mobility [14]. In this study, Koshak has developed a Web-based GIS for Hajj traffic plan [14].

GIS is also used in water resources since engineers, for example, must understand where their pipes, valves, pumps, meters, etc., are located. The Ministry of Water and Electricity (MOWE) in Saudi Arabia is currently using GIS for these same reasons. The location and usage of water and where customers are residing are factors that need to be known. Engineers, managers, etc., also need to know what projects are under construction and 
the facilities requiring repair [15]. MOWE in Saudi Arabia has adopted GIS and initially in the Riyadh core area, this process starting in 2003 and then in Dammam core area in 2004 [16]. Following that GIS was integrated in many of the major cities using the Integrated Water Resources Management System [17]. This paper will examine the adoption of GIS in MOWE and evaluate some determinants and test their impact on MOWE's employees' perceptions of GIS and how these affect the actual usage of GIS. Then the outcomes of this adoption will be evaluated.

\section{Methods}

The method used to collect data from employees was the survey. Our survey was divided into four sections, these consisting of questions about demography, GIS usage, perception of GIS and determinants and benefits of utilizing GIS. The perceptions of GIS and the determinants and benefits questions have one type of question, which is on a 7-point Likert-type scale, serving to measure the level of employees' agreement (1-Strongly disagree, 2-Disagree, 3-Somewhat disagree, 4-Neither agree or disagree, 5-Somewhat agree, 6-Agree, 7Strongly agree) [18]. The survey was an online survey sent to MOWE's employees. The number of people who participated in this survey was 297 who worked in different branches of MOWE throughout Saudi Arabia.

\subsection{Items and Sources}

The items used in this research have been utilized in previous studies, which mean they have already been validated. Table 1 contains all relevant information concerning the items, a brief explanation about each item and the sources of each item.

\subsection{Statistical Techniques}

In this paper, many statistical analysis techniques were used, which are frequency distribution, reliability and validity analysis, correlation analysis and regression analysis. The frequency distribution analysis explained the participants' demographic information. The frequency distribution for any data can be shown in many different methods and one of these concerns the frequency tables used in this paper to display participants' demographic information [19]. The reliability and validity analysis were conducted to confirm that the survey's constructs are reliable and valid. Correlation analysis indicated the relationships between: firstly, the determinants and perceptions of GIS; secondly, perceptions of GIS and the usage of GIS; and thirdly, the usage of GIS and outcomes of such use. A regression analysis was performed in this paper to examine the effects of independent variables on dependent variables.

Table 1. Items' explanations and sources.

\begin{tabular}{|c|c|c|}
\hline Items & Explanation & Source \\
\hline GIS training & $\begin{array}{l}\text { GIS training was measured by the degree of training provided to } \\
\text { MOWE's employees }\end{array}$ & {$[31][33][34]$} \\
\hline Incentives & $\begin{array}{c}\text { Incentives are the personal motivations and beliefs about the } \\
\text { consequences of using GIS }\end{array}$ & {$[34][40]$} \\
\hline Managerial support & $\begin{array}{l}\text { Managerial support was measured according to the resources and } \\
\text { help provided by the organization's management }\end{array}$ & {$[34][52]$} \\
\hline IT expertise & Employees' prior IT experience and skills & {$[6][34]$} \\
\hline $\begin{array}{l}\text { Exposure to GIS technology } \\
\text { (Computer self-efficacy) }\end{array}$ & $\begin{array}{c}\text { Extent to which employees are comfortable in dealing with GIS and } \\
\text { their previous GIS experience. }\end{array}$ & {$[34][46]$} \\
\hline Perception toward GIS & Employees' attitude regarding the use of GIS & {$[40][48]$} \\
\hline Adoption of GIS & GIS usage & {$[31][34][66]$} \\
\hline Efficient decision-making & The efficiency of employees' own decision-making & {$[48][50]$} \\
\hline Cost savings & GIS adoption's effect on cost savings & {$[40][51][52]$} \\
\hline Enhanced risk management & $\begin{array}{l}\text { Risk management identifies the risks that may occur in the future and } \\
\text { try to find solutions to avoid o reduce them [29] }\end{array}$ & {$[34][50][52]$} \\
\hline Improved customer relationships & Connection and communication between employees and customers & {$[50][51][55][56]$} \\
\hline
\end{tabular}




\section{Theoretical Framework}

Several models have been used to study the adoption of GIS technology in MOWE. The theories used in this research were Innovation Diffusion Theory (IDT), Technology Acceptance Model (TAM), TAM2, Theory of Reasoned Action (TRA) and the Unified Theory of Acceptance and Use of Technology (UTAUT). Innovation Diffusion Theory (IDT) has been used since the 1950s, but was succeeded by Rogers' introduction of the most well-known and commonly used innovation-decision process in 1962 [20]. This theory describes the process of accepting or rejecting a new innovation. Making a decision about a particular innovation goes through five steps, which are called the IDT stages [20]. The first stage is when the individual gets to know the innovation and how a new technology functions, its purpose and the need for it. The second stage occurs when the individual likes or dislikes this new technology. There are five attributes that encourage an individual to like a new technology and affect their decision: relative advantage, compatibility, complexity, trialability and observability. After that a decision is made to accept or reject the technology, which is the third stage. The fourth stage is the implementation of this new technology while the fifth stage confirms the decision made by the individual [21].

The Theory of Reasoned Action (TRA) was developed by Ajzen and Fishbein in 1975 [22] [23]. This theory can be used in studies referring to people's attitude-behaviour relationships [24]. In this theory, it is believed that personal beliefs influence attitude and social norms will in turn shape the individual's behaviour toward the action [22]. There are two main constructs of intention in the theory of reasoned action, these being attitude toward the behaviour and the behaviour that a person or a decision-maker enacts when social pressure is put on them. This is known as the subjective norm [22].

The Technology Acceptance Model (TAM) grew out of the TRA model and was devised by Davis [25]. TAM is the most accepted of all the technology adoption models [23]. TAM consists of three main parts that influence the behavioural intention and actual usage of a particular technology: perceived usefulness, perceived ease of use and the users' attitudes that affect the behavioural intention [26]. This intention is determined by both users' perceptions and attitudes regarding the technology and its perceived usefulness. Attitude is determined by both perceived usefulness of the technology and its perceived ease of use [25].

TAM2 was introduced by Venkatesh and Davis [27] in their research paper titled "A Theoretical Extension of the Technology Acceptance Model: Four Longitudinal Field Studies". This model represented an extension of the original Technology Acceptance Model (TAM) and its main purpose was to add more determinants to the original TAM so that perceived usefulness and the intention to use the technology could be better measured. These determinants include social influences that emerge in the context of subjective norm, voluntariness and image. Other determinants comprise job relevance, output quality and result demonstrability which can all affect perceived usefulness. Another important thing that this extended model wants to understand is how the effects of social influence change with different experience levels that users have. It also looks at how the intention to use the technology varies when the usage is voluntary [28].

The Unified Theory of Acceptance and Use of Technology (UTAUT) was developed by Venkatesh et al. (2003) [28]. It is a theory consisting of four main determinants that directly affect the intention to use new technologies: performance expectancy, effort expectancy, social influence and facilitating conditions. This theory also comprises four moderators that can affect the direct four core determinants, i.e. gender, age, experience and voluntariness of use [28].

\section{Research Model}

The research model was constructed based on the existing theories mentioned previously. The research model looks at three parts and tests their impact on each other. The first part of this model consists of five determinants that may affect the perception of GIS. These determinants are GIS training, incentives, managerial support and exposure to GIS. These determinants' impact on people's perceptions of GIS that are going to be tested will be the most significant. The model's second part looks at the impact of perception of GIS on the actual usage of GIS, which will also be tested. The third part tests the actual usage and adoption of GIS. Four outcomes will be tested: efficient decision-making, cost saving, enhanced risk management and improved customer satisfaction. The context being investigated will be the Ministry of Water and Electricity (MOWE) in Saudi Arabia (see Figure 1).

\section{Literature Review and Hypotheses Development}

Geographic Information Systems (GIS) are applied to any science that deals with a location-related phenomenon 
Determinants Adoption Outcomes

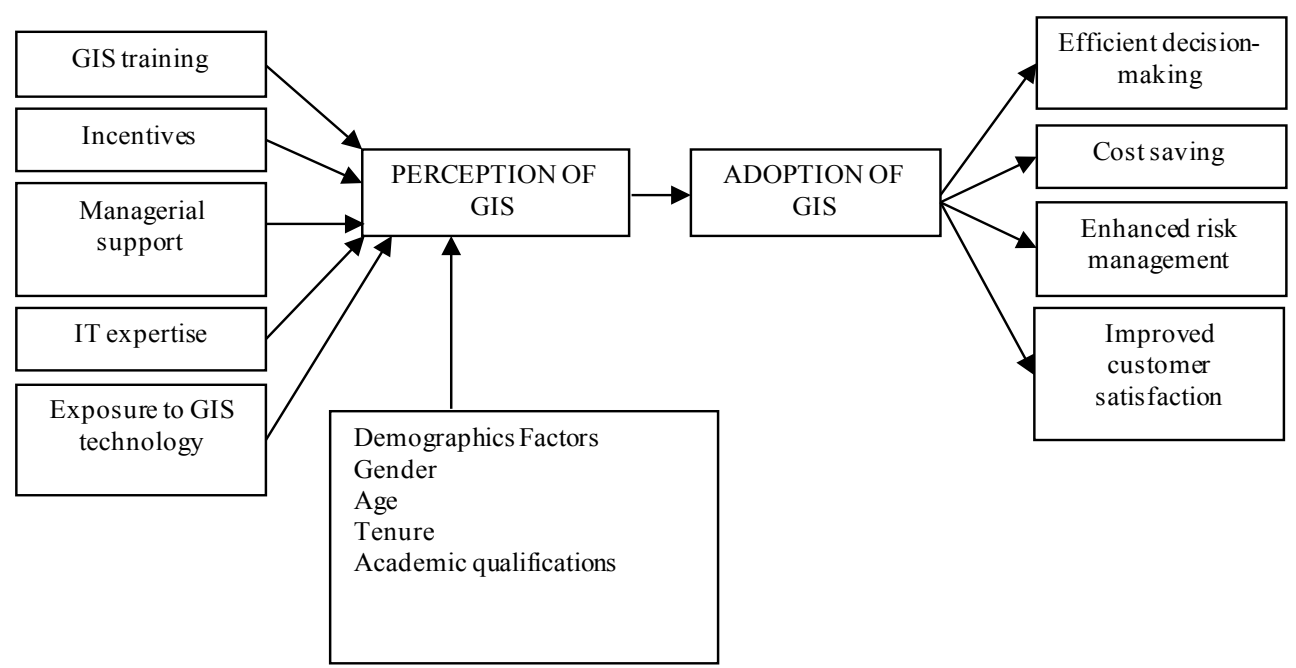

Figure 1. Research model.

on Earth. Some examples of these are the climate in different parts of the planet and how climate change can affect the distribution and spread of diseases. It can also help in detecting the distribution of crimes in various areas, distribution of plants and animals, etc. There are many applications of GIS that can help humans such as Global Positioning System (GPS) in finding locations and managing services and resources [29]. All activities such as building, digging ditches, burying pipelines and cables, finding oil and many other activities, can be documented using GIS [3]. Geographic Information Systems (GIS) keep track of such activities and where they occurred or left their mark. According to Longley et al. (2011, p.4), almost everything that happens, happens somewhere. Knowing where something happens can be critically important [3].

We use GIS in our daily lives, for example asking for a direction to get somewhere. We also use GIS to solve problems in many areas such as health care, such as deciding where to build a new hospital in a particular area and why. Delivery companies send things using different routes every day so the decisions they have to make concerning which routes their vehicles should take will solve geographical problems. Some people cannot decide whether their specific problem is geographical or not. There are three variables that can help in deciding if this is the case. The first is that the problem has a question of scale. The second is the purpose of the problem and whether they use geographic data to analyze the issue. The third is the time scale of the problem and whether geographic problems have persisted for a specific period of time [3]. In this way, "GIS does a better job of sharing data and information than knowledge, which is more difficult to detach from the knower" [3].

There are three relationships in the research model that need to be tested and looked at in detail. The first relationship is between determinants and perception of GIS. Determinants consist of five factors that can affect MOWE's employees' opinions concerning GIS. These five determinants' impacts will be tested in the form of hypotheses as described in more detail below.

\subsection{GIS Training}

Training programs are important for employees because they can help staff increase their knowledge of newly introduced technologies. These programs will result in employees having a positive perception about using new technologies [30]. It is important that organizations have training programs in their culture because it is significant when new technologies are adopted [30]. Training in this context refers to the training provided to staff at MOWE, and it will provide employees with knowledge and practical skills in using a new technology [31]. Employees will develop their self-confidence and level of skills when applying new technologies [32]. GIS training was measured by the amount of training given to MOWE employees. Participants in this survey were asked about the level of training provided to them and how internal training courses would improve their GIS usage abilities. Five questions were devised to obtain employees' opinions on GIS training provided to them. These 
five questions were constructed according to Al-Gahtani and King (1999), Talukder (2014) and Gosh and Glott (2005) [31] [33] [34]. The hypothesis that will be tested is:

H1: GIS training impacts on employees' perceptions of GIS.

\subsection{Incentives}

Incentive can be defined as what a person thinks and perceives the benefits to be of introducing a new technology into the firm [35]-[37]. A person's perception of an innovation is very important as it might change people's behaviour regarding whether they accept this innovation [38]. Adoption of new technologies is expected to enable institutions meet their goals and benefits more efficiently. In order to reinforce employees' perception of the advantage of adopting new technologies, management should give them individual behavioural motivators that encourage them to adopt new technologies [39]. In this research incentives are employees' motivations and beliefs about the consequences of using GIS in MOWE. Participants were asked to rate their level of agreement or disagreement concerning four items developed by Kurnia et al. (2006) and Talukder (2014) [34] [40]. The second hypothesis that will be tested is:

H2: Incentives impact on employees' perceptions of GIS.

\subsection{Managerial Support}

Managerial support is a very important variable that can affect employees' perceptions of adopt new innovation in the workplace [25]. Previous studies discovered that managerial support is associated with the adoption of new technology. It was also found by other studies that managerial support has a positive impact on employees' adoption of new technologies [41]. The more that an organization offers managerial support to employees the more likely they are to accept and utilize new technologies. However, the lack of managerial support is considered to be a problem to such an adoption [42]. This determinant will be tested as follows:

H3: Managerial support impacts on employees' perceptions of GIS.

\subsection{IT Expertise}

People's prior experience refers to their skills and what they know about an innovation beforehand [43] [44]. In this case employees' IT expertise means their level of skills and experience about Information Technology (IT). IT expertise was measured according to workers' prior experience and skills and from where they were acquired. Participants were asked to rate their level of agreement or disagreement on four items that were constructed according to Talukder (2014) and Al-Gahtani and King (1999) [31] [34]. The hypothesis to be tested is as follows:

H4: IT expertise impacts on employees' perceptions of GIS.

\subsection{Exposure to GIS Technology (Computer Self-Efficacy)}

Employees' exposure to a particular technology refers to their previous experience [43] [44]. Each employee has their own beliefs about what they are capable of when using GIS and solving related problems [45]. This means in effect how comfortable are employees when using GIS? This determinant tests employees' abilities to deal with GIS in MOWE according to their exposure to this technology. The determinant was constructed according to Sanchez and Hueros (2010) and Talukder (2014) [34] [46]. Five questions were asked to obtain information on this determinants' impact on employees' perceptions of GIS. The hypothesis that will be tested is:

H5: Exposure to GIS technology impacts on employees' perceptions of GIS.

\subsection{Perception of GIS}

The second relationship in the research model is that between perception of GIS and the adoption (usage) of GIS. Perception is the same as attitude when using this technology, and in particular employees' positive or negative feelings about it [47]. Consequently, MOWE employees' attitude to the use of GIS is measured. Five questions were constructed based on Cakar (2011) and Kurnia et al. (2006) to test MOWE's employees' perceptions of and feelings about GIS [40] [48]. The impact of perception on GIS adoption and its usage will be tested as a hypothesis in the following way:

H6: Perceptions of GIS affect the actual usage of GIS.

The third relationship is between the adoption of GIS (usage) and the benefits of adopting such technology in 
an organization, in this case the Ministry of Water and Electricity (MOWE) in Saudi Arabia. The hypotheses in this relationship are explained in more detail below.

\subsection{Efficient Decision-Making}

Decision-making is the process of choosing an option out of many that are available [49]. Decision-making plays a big role in organizations as it can sometimes lead to good or bad outcomes [49]. In this paper the impact of actual usage on enhancing employees' decision- making will be tested [48]. The items measuring the level of decision-making were constructed based on the work by Abu-Al-Aish and Love (2013) and Cakar (2011) [48] [50]. Items were edited to suit this variable. The hypothesis that will be tested is:

H7: Usage of GIS leads to efficient decision-making.

\subsection{Cost Savings}

This variable was constructed to measures if costs are reasonable and if the GIS are cost-effective. The items below were developed with reference to Kurnia et al. (2006), Kim and Ammeter (2014) and Oliveira et al. (2014) [40] [51] [52]. This will test if the actual usage of GIS will lead to costs being saved. A study by Kurnia 2006, found that perceived cost does not have an impact on either attitude to using an innovation or usage intentions [40]. The hypothesis that will be tested is:

H8: Usage of GIS leads to cost savings.

\subsection{Enhanced Risk Management}

Risk management is defined as identifying the risks that may occur in the future and try to find solutions to them so dangers will be averted [53]. The items that measure the level of risk management were constructed according to Abu-Al-Aish and Love (2013), Talukder (2014) and Oliveira et al. (2014) [34] [50] [52]. The test will measure the impact of actual GIS usage on enhancing risk management in MOWE. Subsequently the hypothesis to be tested is:

H9: Usage of GIS leads to enhanced risk management.

\subsection{Improved Customer Relationships}

Improved customer relationships refer to better communication between employees and customers [54]. Items that measure such improvements were constructed based on the work by Phichitchaisopa and Naenna (2013), Kim and Ammeter (2014), Alharbi and Drew (2014) and Abu-Al-Aish and Love (2013) [50] [51] [55] [56]. They have been edited to suit this variable. The test will be on the impact of actual GIS usage on improved customer relationships in MOWE.

H10: Usage of GIS leads to improved customer relationships.

\section{Results}

\subsection{Participants' Demographic Information}

Demographic factors refer to factors that identify participants and their characteristics in terms of gender, age, tenure, academic qualification and their usage and perception of Geographic Information Systems (GIS). In the survey, all participants were male employees because in the Ministry of Water and Electricity (MOWE), Water Sector, only men worked there so the percentage was $100 \%$ male. The participants' age categories were diverse in that $42 \%$ were in the $18-30$ age category, while most participants were in the $31-40$ age group (51\% of all age groups). Furthermore 5\% fell under the $41-45$ age groups and the smallest age group (2\%) consisted of participants who were 46 to 65 years of age. No-one in the group was 65 or older. Most participants (91\%) are full-time employees and only a few $(9 \%)$ work on a part-time basis. Most employees (86\%) are permanent and only $14 \%$ work at MOWE on a temporary or contract basis. Participants' academic qualifications vary in that $8 \%$ have their secondary certificate, $19 \%$ have a diploma, while the majority $(56 \%)$ have a Bachelor degree. In terms of postgraduate qualifications, $17 \%$ hold a Master's degree. Table 2 summarizes participants' demographic information. 
Table 2. Demographic information of participants.

\begin{tabular}{|c|c|c|}
\hline Characteristics & Frequency & Percentage \\
\hline \multicolumn{3}{|l|}{ Gender } \\
\hline Male & 221 & 100 \\
\hline \multicolumn{3}{|l|}{ Age } \\
\hline $18-30$ & 94 & 42.5 \\
\hline $31-40$ & 112 & 50.7 \\
\hline $41-45$ & 11 & 5.0 \\
\hline $46-65$ & 4 & 1.8 \\
\hline \multicolumn{3}{|l|}{ Employed as } \\
\hline Full time & 201 & 91.0 \\
\hline Part time & 20 & 9.0 \\
\hline \multicolumn{3}{|l|}{ Tenure } \\
\hline Permanent & 191 & 86.4 \\
\hline Temporary & 30 & 13.6 \\
\hline \multicolumn{3}{|l|}{ Education } \\
\hline Secondary & 18 & 8.1 \\
\hline College & 43 & 19.5 \\
\hline Bachelor & 123 & 55.7 \\
\hline Master & 37 & 16.7 \\
\hline Total & 221 & 100 \\
\hline
\end{tabular}

\subsection{Reliability and Validity of Constructs}

A reliability and validity test was done to confirm the survey's constructs are reliable and valid. Table 3 represents the reliability in terms of Cronbach's alpha for all dependent and independent variables. Reliability values between 0.70 and 0.80 are considered to be "respectable" while those between 0.80 and 0.90 are deemed "very good" [57]. The Cronbach's alpha coefficient shows that the results are highly reliable as the Cronbach's alpha coefficient ranges from 0.692 to 0.962 ; this means that the data has a high internal consistency [58]. A lower limit for Cronbach's alpha was agreed upon, whereby 0.70 and the lower limit can decrease if the research was an exploratory research [59]. Table 3 also shows the Average Variance Extracted (AVE) and the factor loadings of the items that measure the validity of the constructs. It is considered to be proof of an acceptable validity level if the AVE is greater than 0.50 [60], which means that "at least $50 \%$ of the measurement variance is to be captured by the constructs" [34] [60]. The results of the collected data reveal that the AVE ranges from 0.733 to 0.932 , which is considered highly acceptable. Based on both Cronbach's alpha and AVE results, it can be concluded that the constructs are reliable and valid enough to measure the drivers of using GIS, perceptions of using GIS and the actual usage of GIS.

\subsection{Correlations}

The Pearson correlations were calculated for all variables included in this paper. These calculations show the relationships between the determinants in relation to perceptions of GIS and the relationship between them and the usage of GIS (see Table 4). These calculations also indicate the relationship between the usage of GIS and outcome variables (see Table 5). The results show there is no relationship between perception of GIS and training. Results reveal that the level of perception is significant and positively related to incentives $(\mathrm{r}=0.164, p<$ $0.05)$ and negatively related to managerial support $(\mathrm{r}=-0.336, p<0.01)$. These results reveal that perceptions of GIS are significant and positively related to IT experience $(\mathrm{r}=0.256, p<0.01)$ and exposure to GIS $(\mathrm{r}=0.391, p$ $<0.01)$. There is also a positive relationship between perception of GIS and level of usage $(\mathrm{r}=0.470, p<0.01)$. 
Table 3. Reliability and convergent validity results.

\begin{tabular}{|c|c|c|c|}
\hline Factor & Factor Loading & Cronbach's Alpha & AVE \\
\hline Usage & & 0.937 & 0.905 \\
\hline USE1 & 0.910 & & \\
\hline USE2 & 0.953 & & \\
\hline USE3 & 0.918 & & \\
\hline USE4 & 0.873 & & \\
\hline USE5 & 0.867 & & \\
\hline Training & & 0.895 & 0.844 \\
\hline TRA1 & 0.868 & & \\
\hline TRA2 & 0.906 & & \\
\hline TRA3 & 0.871 & & \\
\hline TRA4 & 0.775 & & \\
\hline TRA5 & 0.795 & & \\
\hline Incentives & & 0.838 & 0.834 \\
\hline INC1 & 0.806 & & \\
\hline INC2 & 0.874 & & \\
\hline INC3 & 0.872 & & \\
\hline INC4 & 0.611 & & \\
\hline INC5 & 0.784 & & \\
\hline Managerial Support & & 0.866 & 0.808 \\
\hline MSP1 & 0.731 & & \\
\hline MSP2 & 0.848 & & \\
\hline MSP3 & 0.909 & & \\
\hline MSP4 & 0.814 & & \\
\hline MSP5 & 0.724 & & \\
\hline IT Expertise & & 0.906 & 0.885 \\
\hline ITE1 & 0.901 & & \\
\hline ITE2 & 0.921 & & \\
\hline ITE3 & 0.884 & & \\
\hline ITE4 & 0.830 & & \\
\hline Exposure to GIS & & 0.962 & 0.932 \\
\hline EXG1 & 0.925 & & \\
\hline EXG2 & 0.934 & & \\
\hline EXG3 & 0.921 & & \\
\hline EXG4 & 0.929 & & \\
\hline EXG5 & 0.952 & & \\
\hline Perceptions of GIS & & 0.836 & 0.786 \\
\hline POG1 & 0.896 & & \\
\hline POG2 & 0.900 & & \\
\hline POG3 & 0.900 & & \\
\hline POG4 & 0.717 & & \\
\hline POG5 & 0.396 & & \\
\hline Efficient Decision-Making & & 0.778 & 0.733 \\
\hline EDM1 & 0.732 & & \\
\hline EDM2 & 0.851 & & \\
\hline EDM3 & 0.776 & & \\
\hline EDM4 & 0.766 & & \\
\hline EDM5 & 0.486 & & \\
\hline Cost Savings & & 0.740 & 0.891 \\
\hline COS2 & 0.891 & & \\
\hline COS5 & 0.891 & & \\
\hline Enhanced Risk Management & & 0.820 & 0.807 \\
\hline ERM1 & 0.819 & & \\
\hline ERM2 & 0.754 & & \\
\hline ERM3 & 0.815 & & \\
\hline ERM4 & 0.838 & & \\
\hline \multicolumn{4}{|l|}{ Improved Customer Relationships } \\
\hline ICR3 & 0.875 & 0.692 & 0.875 \\
\hline ICR4 & 0.875 & & \\
\hline
\end{tabular}


Table 4. Inter-correlations among variables.

\begin{tabular}{cccccccc}
\hline & 1 & 2 & 3 & 4 & 5 & 6 & 7 \\
\hline 1. TRA & 1.000 & 0.041 & $0.361^{\mathrm{a}}$ & $0.350^{\mathrm{a}}$ & $0.386^{\mathrm{a}}$ & 0.112 & 0.080 \\
2. INC & 0.041 & 1.000 & $0.132^{\mathrm{c}}$ & $0.439^{\mathrm{a}}$ & $0.276^{\mathrm{a}}$ & $0.452^{\mathrm{a}}$ & $0.164^{\mathrm{c}}$ \\
3. MSP & $0.361^{\mathrm{a}}$ & $0.132^{\mathrm{c}}$ & 1.000 & $0.216^{\mathrm{a}}$ & 0.105 & -0.035 & $-0.336^{\mathrm{a}}$ \\
4. ITE & $0.350^{\mathrm{a}}$ & $0.439^{\mathrm{a}}$ & $0.216^{\mathrm{a}}$ & 1.000 & $0.280^{\mathrm{a}}$ & $0.382^{\mathrm{a}}$ & $0.256^{\mathrm{a}}$ \\
5. EXG & $0.386^{\mathrm{a}}$ & $0.276^{\mathrm{a}}$ & 0.105 & $0.280^{\mathrm{a}}$ & 1.000 & $0.426^{\mathrm{a}}$ & $0.391^{\mathrm{a}}$ \\
6. USE & 0.112 & $0.452^{\mathrm{a}}$ & -0.035 & $0.382^{\mathrm{a}}$ & $0.426^{\mathrm{a}}$ & 1.000 & $0.470^{\mathrm{a}}$ \\
7. POG & 0.080 & $0.164^{\mathrm{c}}$ & $-0.336^{\mathrm{a}}$ & $0.256^{\mathrm{a}}$ & $0.391^{\mathrm{a}}$ & $0.470^{\mathrm{a}}$ & 1.000 \\
\hline
\end{tabular}

${ }^{a}$ Correlation is significant at the 0.01 level (2-tailed). ${ }^{\mathrm{c} C o r r e l a t i o n}$ is significant at the 0.05 level (2-tailed). TRA $=$ Training, $\mathrm{INC}=$ Incentives, $\mathrm{MSP}=$ Managerial support, ITE $=$ IT experience, $\mathrm{EXG}=$ Exposure to GIS, $\mathrm{POG}=$ Perception of GIS.

Table 5. Inter-correlations among variables.

\begin{tabular}{rccccc}
\hline & 1 & 2 & 3 & 4 & 5 \\
\hline 1. USE & 1.000 & 0.055 & 0.092 & $0.141^{\mathrm{c}}$ & $0.477^{\mathrm{a}}$ \\
2. EDM & 0.055 & 1.000 & $0.910^{\mathrm{a}}$ & -0.031 & $0.165^{\mathrm{c}}$ \\
3. COS & 0.092 & $0.910^{\mathrm{a}}$ & 1.000 & -0.076 & 0.115 \\
4. ERM & $0.141^{\mathrm{c}}$ & -0.031 & -0.076 & 1.000 & $0.225^{\mathrm{a}}$ \\
5. ICR & $0.477^{\mathrm{a}}$ & $0.165^{\mathrm{c}}$ & 0.115 & $0.225^{\mathrm{a}}$ & 1.000 \\
\hline
\end{tabular}

${ }^{\mathrm{a}}$ Correlation is significant at the 0.01 level (2-tailed). ${ }^{\mathrm{c}}$ Correlation is significant at the 0.05 level (2-tailed). USE $=$ Usage, $\mathrm{EDM}=$ Efficient decision-making, $\mathrm{COS}=$ Cost savings, ERM = Enhanced risk management, ICR = Improved customer relationships.

The results also show that at the other end of the research model there is no significance at all between usage and efficient decision-making or cost savings. However, there is a significantly positive relationship between usage and enhanced risk management $(\mathrm{r}=0.141, p<0.05)$ and improved customer relationships $(\mathrm{r}=0.477, p<$ 0.01 ) in the outcomes.

\subsection{Regression Analysis}

The regression analysis collected data on how independent variables impact on dependent variables. In this paper regression analysis was undertaken to assess how determinants influenced the perception of using GIS, the impact of this perception on usage and impact of usage on outcomes. The results from the multiple regression analysis regarding perception of GIS as a dependent variable support the model fit at the $1 \%$ level of significance with an $\mathrm{r}^{2}$ of $35.0 \%$. Based on the independent variables, managerial support, IT expertise and exposure to GIS were found to be significant at the level of Sig $<0.001$. Training and incentives show no significance with perception of GIS (see Table 6). Table 7 presents the results of multiple regression analysis with usage as a dependent variable and perception of GIS as an independent variable. In Table 7, results indicate with usage as a dependent variable that there is significance at $\mathrm{Sig}<0.001$, which supports the model, fit at the $1 \%$ level of significance with an $\mathrm{r}^{2}$ of $22.1 \%$. Table 8 summarizes the results of the multiple regression analysis with usage as an independent variable and each of the outcomes as dependent variables. Results show that usage has no significance for efficient decision-making and cost savings. However, it emerged that improved customer relationships is significant with $\mathrm{Sig}<0.000$, and enhanced risk management is significant at $\mathrm{Sig}<0.05$.

\section{Discussion of Results}

In this discussion of results, the hypotheses will be discussed in detail regarding their significance and the test results for each one. Table 9 highlights the results of hypotheses testing and briefly summarizes the findings. 
Table 6. Results of multiple regression analysis with perception of GIS as a dependent variable.

\begin{tabular}{|c|c|c|c|c|c|c|}
\hline Dependent Variable & Perception of GIS & & & & & \\
\hline Independent Variables & Unstand. Coef. B & Standard Coef. ${ }^{\beta}$ & $\mathrm{T}$ & $R$ Square & $F$ & Sig. \\
\hline & & & & 0.350 & 23.193 & 0.000 \\
\hline Training & 0.013 & 0.013 & 0.191 & & & 0.849 \\
\hline Incentives & 0.017 & 0.017 & 0.265 & & & 0.791 \\
\hline Managerial support & -0.432 & -0.432 & -7.235 & & & 0.000 \\
\hline IT expertise & 0.237 & 0.237 & 3.590 & & & 0.000 \\
\hline Exposure to GIS & 0.360 & 0.360 & 5.776 & & & 0.000 \\
\hline
\end{tabular}

Table 7. Results of multiple regression analysis with usage as a dependent variable and perception of GIS as an independent variable.

\begin{tabular}{ccccccc}
\hline Dependent Variable & Usage & & & & \\
\hline Independent Variables & Unstand. Coef. B & Standard Coef. $\beta$ & $T$ & $R$ Square & $F$ & Sig. \\
\hline & & & & 0.221 & 62.103 & 0.000 \\
Perception of GIS & 0.470 & 0.470 & 7.881 & & 0.000 \\
\hline
\end{tabular}

Table 8. Results of multiple regression analysis with usage as an independent variable.

\begin{tabular}{cccccccc}
\hline Independent Variable & Usage & & & & & \\
\hline Dependent Variables & Unstand. Coef. B & Standard Coef. ${ }^{\beta}$ & $T$ & $R$ Square & $F$ & Sig. \\
\hline & & & & & 0.000 \\
Decision-making & 0.055 & 0.055 & 0.814 & 0.003 & 0.663 & 0.416 \\
Cost savings & 0.092 & 0.092 & 1.371 & 0.009 & 1.879 & 0.172 \\
Risk Management & 0.141 & 0.141 & 2.105 & 0.020 & 4.429 & 0.036 \\
Customer Relationships & 0.477 & 0.477 & 8.033 & 0.228 & 64.523 & 0.000 \\
\hline
\end{tabular}

Table 9. Results of hypotheses.

\begin{tabular}{|c|c|c|}
\hline Hypotheses & Results & Summary of findings \\
\hline $\begin{array}{l}\text { H1: GIS training impacts on employees' } \\
\text { perceptions of GIS }\end{array}$ & No significant impact found & $\begin{array}{l}\text { GIS training has no impact on employees' } \\
\text { perceptions of GIS }\end{array}$ \\
\hline $\begin{array}{l}\text { H2: Incentives impact on employees' } \\
\text { perceptions of GIS }\end{array}$ & No significant impact found & $\begin{array}{c}\text { Incentives have no impact on employees' perceptions of } \\
\text { GIS. However, there is a relationship between the two } \\
\text { variables }\end{array}$ \\
\hline $\begin{array}{l}\text { H3: Managerial support impacts on } \\
\text { employees' perceptions of GIS }\end{array}$ & Significant & $\begin{array}{l}\text { Managerial support has an impact on and } \\
\text { relationship with employees' perceptions of GIS }\end{array}$ \\
\hline $\begin{array}{c}\text { H4: IT expertise impacts on employees' } \\
\text { perceptions of GIS }\end{array}$ & Significant & $\begin{array}{l}\text { IT expertise has an impact on and relationship with } \\
\text { employees' perceptions of GIS }\end{array}$ \\
\hline $\begin{array}{l}\text { H5: Exposure to GIS technology impacts } \\
\text { on employees' perceptions of GIS }\end{array}$ & Significant & $\begin{array}{l}\text { Exposure to GIS technology has an impact on and } \\
\text { relationship with employees' perceptions of GIS }\end{array}$ \\
\hline $\begin{array}{c}\text { H6: Perception of GIS affects the actual } \\
\text { usage of GIS }\end{array}$ & Significant & $\begin{array}{l}\text { Perception of GIS has an impact on and } \\
\text { relationship with the actual usage of GIS }\end{array}$ \\
\hline $\begin{array}{l}\text { H7: Usage of GIS leads to efficient } \\
\text { decision-making }\end{array}$ & No significant impact found & $\begin{array}{l}\text { Usage of GIS has no impact on efficient } \\
\text { decision-making }\end{array}$ \\
\hline H8: Usage of GIS leads to cost savings & No significant impact found & Usage of GIS has no impact on cost savings \\
\hline $\begin{array}{c}\text { H9: Usage of GIS leads to enhanced risk } \\
\text { management }\end{array}$ & Significant & $\begin{array}{c}\text { Usage of GIS has an impact on and relationship with } \\
\text { enhanced risk management }\end{array}$ \\
\hline $\begin{array}{l}\text { H10: Usage of GIS leads to improved } \\
\text { customer relationships }\end{array}$ & Significant & $\begin{array}{l}\text { Usage of GIS has an impact on and relationship with } \\
\text { improved customer relationships }\end{array}$ \\
\hline
\end{tabular}




\subsection{Hypotheses 1, 2, 3, 4 and 5}

Hypotheses 1 to 5 are the determinants that were tested to evaluate whether they impact on employees' perceptions of GIS or not. Hypotheses 1 and 2 were tested and it was found that GIS training and incentives have no impact on perception. The reason for this may be that the participants' sample who filled the survey and used for this paper may have previous GIS experience, which is why training results showed that it did not impact employees' perception toward GIS. Incentives also did not have an impact on perception of GIS because employees believe GIS helps in their actual work duties, not in self-organization. Hypotheses 3, 4 and 5 are significant and also have a relationship with perception of GIS. This means that managerial support, IT expertise and exposure to GIS impact on people's perceptions of GIS.

\subsection{Hypothesis 6}

Hypothesis 6 was designed to test if perception of GIS has an impact on the usage of GIS. Regression analysis shows that the results are consistent with previous studies regarding the relationship and impact between the two variables perception of GIS and its usage [46] [47] [61]-[64]. Findings for the impact of perception of GIS on its usage were significant and a link was detected between the two variables.

\subsection{Hypotheses 7, 8, 9 and 10}

Hypotheses 7 to 10 are concerned with the impact of usage on the outcomes. The regression analysis for these hypotheses showed that there was no significant impact found between usage and decision-making, which was unexpected as most GIS studies assert that GIS helps to make good decisions [5] [6] [8] [9]. This was the case in MOWE. It may suggest that MOWE's employees did not receive GIS training, and explains why they are not using it properly and not noticing the big difference GIS made in making good decisions. Usage also did not have any significant impact on cost savings, as many of MOWE's projects have still not been completed. This may be the reason or it could be that many participants only operated GIS to execute tasks and did not concentrate on its cost aspects. There are some finance experts who are responsible for projects' costs and these participants constitute a minority in this study as there are only a few of them in each branch. Hypotheses 9 to10 which stated the usage impact on enhanced risk management and improved customer satisfaction were significant. This means that usage of GIS has an impact on and relationship with enhanced risk management and improved customer relationships.

\section{Conclusion and Implications}

It can be concluded from the results of this research paper that some determinants impact on MOWE's employees' perceptions of GIS. It is also found that this perception influences actual usage. Some outcomes were tested and some were found to be affected by the actual usage of GIS. Managerial support, IT expertise and exposure to GIS technology have an impact on and relationship with employees' perceptions of GIS. Training and incentives emerged as insignificant determinants that do not impact on employees' perceptions of using GIS; there is, however, a relationship between incentives and perception of GIS. Furthermore there is a strong impact on and relationship between employees' perceptions of GIS and their actual usage of it. When using GIS, there are many benefits that emerge such as efficiency of service, speed of service, quality of service, enhanced risk management and improved customer satisfaction. These are the factors found to be significant and impacted on by GIS usage.

The outcome factors that were found to be insignificant were efficient decision-making and cost savings. Some determinants require more attention from MOWE in order for employees to be more willing to adopt GIS. It is also important to help employees to know the benefits and outcomes from adopting GIS. Staff needs to be trained to obtain the maximum benefits of technology. The impact of actual usage on decision-making and cost savings could become significant if MOWE worked hard on some determinants that can affect employees' behavior when using GIS. This research will benefit the Saudi Arabian government since MOWE is a government department. The government can use the results of this research to implement GIS in other ministries. This research can also help organizationally because: firstly, the government can use results from this research to improve GIS in MOWE; and secondly, make it easier for other departments to adopt GIS according to the results of this research. This analysis can assist managers to understand their employees' behaviors and provide them with the means to change how they perceive GIS. This will enable MOWE to use GIS productively. 


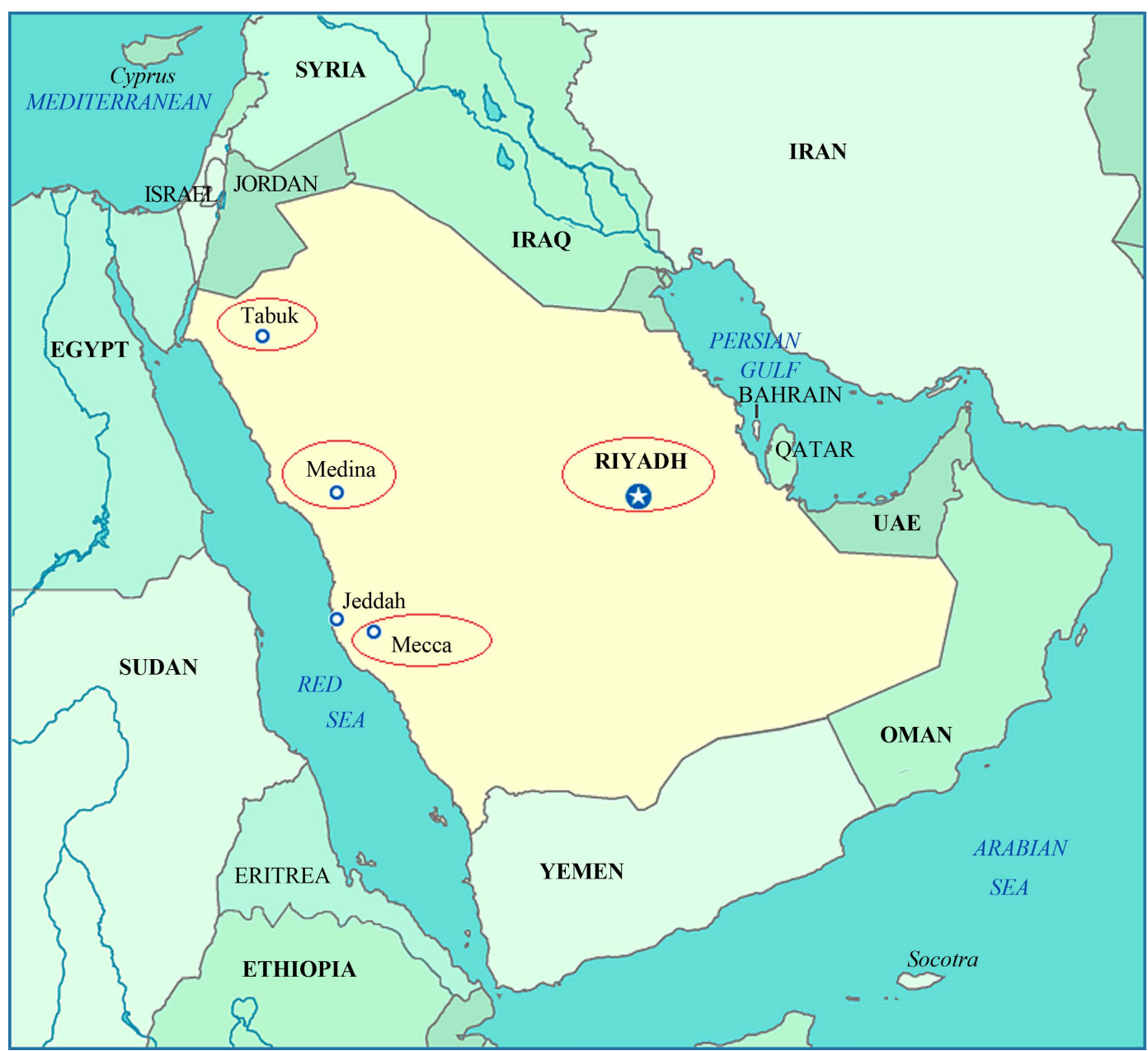

Figure 2. A location map of the study area [65].

\section{Limitations and Future Research}

The main limitation of the research is that data were collected from only four major cities in Saudi Arabia-Madinah, Makkah, Tabuk and Riyadh (see Figure 2). This limited sample may affect the generalizability of the findings across the whole country, which needs to be taken into account when interpreting the results. Future research should look into all departments or ministries having more participants and develop more representative and nation-wide samples that reflect Saudi Arabian workers' adoption behavior of GIS. Finally, future research should use the structural modelling approaches such as SEM or PLS to test the model with a more broadbased sample so that the GIS system adoption is more rigorously researched.

\section{References}

[1] Esri (2011) What Is GIS? http://www.esri.com/what-is-gis

[2] Azeez, M.A. (2013) The Geographical Information Science (Science of Geo-Informatics): A Historical Background, and the Foundations of the Scientific Methods. The 8th GIS Symposium in the Eastern Province, 1, 1-21.

[3] Longley, P.A., Goodchild, M.F., Maguire, D. J. and Rhind, D.W. (2011) Geographic Information Systems and Science. 3rd Edition, Wiley, Hoboken.

[4] Artz, M. (2009) Top Five Benefits of GIS. Viewed 8 June 2016. https://gisandscience.com/2009/09/14/top-five-benefits-of-gis/

[5] Alkobaisi, S., Bae, W.D., Vojtěchovský, P. and Narayanappa, S. (2011) An Interactive Framework for Spatial Joins: A 
Statistical Approach to Data Analysis in GIS. GeoInformatica, 16, 329-355. http://dx.doi.org/10.1007/s10707-011-0134-7

[6] Jaziri, W. and Mainguenaud, M. (2012) A Framework to Model and Manipulate Constraints for Over-Constrained Geographic Applications. GeoInformatica, 17, 257-284. http://dx.doi.org/10.1007/s10707-012-0151-1

[7] Angulo, J.M., Yu, H., Langousis, A., Madrid, A.E. and Christakos, G. (2012) Modeling of Space-Time Infectious Disease Spread under Conditions of Uncertainty. International Journal of Geographical Information Science, 26, 17511772. http://dx.doi.org/10.1080/13658816.2011.648642

[8] Hu, F., Xu, W. and Li, X. (2012) A Modified Particle Swarm Optimization Algorithm for Optimal Allocation of Earthquake Emergency Shelters. International Journal of Geographical Information Science, 26, 1643-1666. http://dx.doi.org/10.1080/13658816.2011.643802

[9] Kwak, H., Lee, W.K., Saborowski, J., Lee, S.Y., Won, M., Koo, K., Lee, M.B. and Kim, S. (2012) Estimating the Spatial Pattern of Human-Caused Forest Fires Using a Generalized Linear Mixed Model with Spatial Autocorrelation in South Korea. International Journal of Geographical Information Science, 26, 1589-1602. http://dx.doi.org/10.1080/13658816.2011.642799

[10] Lloyd, C.D. (2012) Analysing the Spatial Scale of Population Concentrations by Religion in Northern Ireland Using Global and Local Variograms. International Journal of Geographical Information Science, 26, 57-73. http://dx.doi.org/10.1080/13658816.2011.563743

[11] Sposito, V., Bene, K., Pelizaro, C. and Wyatt, R. (2009) Application of GIS-Based Computer Modelling to Planning for Adaption to Climate Change in Rural Areas. Applied GIS, 5, 1-25.

[12] Al-Ramadan, B. (1993) A Framework for a National Effort towards Geographic Information and Geographic Information Systems in Saudi Arabia. Doctoral Thesis, University of Pennsylvania, USA.

[13] Abdulaal, W.A. (2009) Framework for Enterprise GIS for Saudi Municipalities. International Journal of Geographical Information Science, 23, 687-702. http://dx.doi.org/10.1080/13658810701378838

[14] Koshak, N. (2006) Developing a Web-Based GIS for Hajj Traffic Plan (HajjGIS.Net). Journal of Urban Planning Research, 6, 1-13.

[15] Ginther, P. (2015) Use of GIS Growing in the Municipal Water Wastewater Business. Waterworld. http://www.waterworld.com/articles/print/volume-23/issue-4/editorial-feature/use-of-gis-growing-in-the-municipal-wat er-wastewater-business.html

[16] Al-Ramadan, B. (2009) GIS Adoption in Saudi Arabia: Obstacles and Challenges. Petro GIS Conference, Bahrain.

[17] Hajjar, A. (2015) Abdullah T. Hajjar Talks about GIS in Utility Services in Saudi Arabia. Geospatial Survey \& Mapping.

http://geospatialsurvey.net/index.php/2015/09/25/abdullah-t-hajjar-talks-about-gis-in-utility-services-in-sau di-arabia/

[18] Vagias, W.M. (2006) Likert-Type Scale Response Anchors. Clemson International Institute for Tourism \& Research Development, Department of Parks, Recreation and Tourism Management. Clemson University, Clemson. http://www.clemson.edu/centers-institutes/tourism/documents/sample-scales.pdf

[19] Australian Bureau of Statistics (ABS) (2013) Statistical Language: Frequency Distribution. Viewed 13 April 2015. http://www.abs.gov.au/websitedbs/a3121120.nsf/home/statistical+language+-+frequency+distribution

[20] Rogers, E.M. (1962) Diffusion of Innovations. The Free Press, New York.

[21] Rogers, E.M. (1995) Diffusion of Innovations. 4th Edition, the Free Press, New York.

[22] Ajzen, I. and Fishbein, M. (1980) Understanding Attitudes and Predicting Social Behaviour. Prentice-Hall, Englewood Cliffs.

[23] Pelet, J. and Papadopoulou, P. (2014) User Behavior in Ubiquitous Online Environments. IGI Global, Hershey. http://dx.doi.org/10.4018/978-1-4666-4566-0

[24] Kripanont, N. (2007) Examining a Technology Acceptance Model of Internet Usage by Academics within Thai Business Schools. PhD Thesis, Victoria University, Melbourne.

[25] Davis, F.D., Bagozzi, R.P. and Warshaw, P.R. (1989) User Acceptance of Computer Technology: A Comparison of Two Theoretical Models. Management Science, 35, 982-1003. http://dx.doi.org/10.1287/mnsc.35.8.982

[26] López-Nicolás, C., Molina-Castillo, F. and Bouwman, H. (2008) An Assessment of Advanced Mobile Services Acceptance: Contributions from TAM and Diffusion Theory Models. Information and Management, 45, 359-364. http://dx.doi.org/10.1016/j.im.2008.05.001

[27] Venkatesh, V. and Davis, F.D. (2000) A Theoretical Extension of the Technology Acceptance Model: Four Longitudinal Field Studies. Management Science, 46, 186-204. http://dx.doi.org/10.1287/mnsc.46.2.186.11926 
[28] Venkatesh, V., Morris, M.G., Davis, G.B. and Davis, F.D. (2003) User Acceptance of Information Technology: Toward a Unified View. MIS Quarterly, 27, 425-478.

[29] Goodchild, M. (2012) Geographic Information Systems. In: Bainbridge, W., ed., Leadership in Science and Technology: A Reference Handbook, Sage Publications Inc., Thousand Oaks, 738-746. http://dx.doi.org/10.4135/9781412994231.n84

[30] Cooper, R.B. (1994) The Inertial Impact of Culture on IT Implementation. Information \& Management, 27, $17-31$. http://dx.doi.org/10.1016/0378-7206(94)90099-X

[31] Al-Gahtani, S. and King, M. (1999) Attitudes, Satisfaction and Usage: Factors Contributing to Each in the Acceptance of Information Technology. Behaviour and Information Technology, 18, 277-297. http://dx.doi.org/10.1080/014492999119020

[32] Lee, S., Kim, I., Rhee, S. and Trimi, S. (2006) The Role of Exogenous Factors in Technology Acceptance: The Case of Object-Oriented Technology. Information \& Management, 45, 12-23. http://dx.doi.org/10.1016/j.im.2005.11.004

[33] Gosh, R.A. and Glott, R. (2005) Free/Libre and Open Source Software: Policy Support. FLOSSPOLS: Government Survey Report, MERIT, University of Maastricht, Maastricht, 1-103.

[34] Talukder, M. (2014) Managing Innovation Adoption: From Innovation to Implementation. Gower Publication, Surrey.

[35] Chang, M. and Cheung, W. (2001) Determinants of the Intention to Use Internet/WWW at Work: A Confirmatory Study. Information \& Management, 39, 1-14. http://dx.doi.org/10.1016/S0378-7206(01)00075-1

[36] Cheung, W., Chang, M. and Lai, V. (2000) Prediction of Internet and World Wide Web Usage at Work: A Test of an Extended Triandis Model. Decision Support Systems, 30, 83-100. http://dx.doi.org/10.1016/S0167-9236(00)00125-1

[37] Sappington, D. (1991) Incentives in Principal-Agent Relationships. The Journal of Economic Perspectives, 5, 45-66.

[38] Nilakant, V. and Rao, H. (1994) Agency Theory and Uncertainty in Organisations: An Evaluation. Organisation Studies, 15, 649-672.

[39] Bhattacherjee, A. (1998) Managerial Influences on Intra-Organisational Information Technology Use: A Principal-Agent Model. Decision Sciences, 29, 139-162.

[40] Kurnia, S., Smith, S. and Lee, H. (2006) Consumers' Perception of Mobile Internet in Australia. E-Business Review, 5, 19-32.

[41] Trevino, L. and Webster, J. (1992) Flow in Computer-Mediated Communication: Electronic Mail and Voice Mail Evaluation and Impacts. Communication Research, 19, 125-143. http://dx.doi.org/10.1177/009365092019005001

[42] Lee, H., Lee, Y. and Kwon, D. (2005) The Intention to Use Computerized Reservation Systems: The Moderating Effects of Organizational Support and Supplier Incentive. Journal of Business Research, 58, 1552-1561. http://dx.doi.org/10.1016/j.jbusres.2004.07.008

[43] Igbaria, M., Guimaraes, T. and Davis, G. (1995) Testing the Determinants of Microcomputer Usage via a Structural Equation Model. Journal of Management Information Systems, 11, 87-114. http://dx.doi.org/10.1080/07421222.1995.11518061

[44] Igbaria, M., Parasuraman, S. and Baroudi, J. (1996) A Motivational Model of Microcomputer Usage. Journal of Management Information Systems, 13, 127-143. http://dx.doi.org/10.1080/07421222.1996.11518115

[45] Bandura, A. (1977) Self-Efficacy: Toward Unifying Theory of Behaviour Change. American Psychologist, 37, 122147. http://dx.doi.org/10.1037/0003-066X.37.2.122

[46] Sanchez, R.A. and Hueros, A.D. (2010) Motivational Factors that Influence the Acceptance of Moodle Using TAM. Computers in Human Behavior, 26, 1632-1640. http://dx.doi.org/10.1016/i.chb.2010.06.011

[47] Lam, T., Cho, V. and Qu, H. (2007) A Study of Hotel Employee Behavioral Intentions towards Adoption of Information Technology. International Journal of Hospitality Management, 26, 49-65. http://dx.doi.org/10.1016/j.ijhm.2005.09.002

[48] Cakar, B. (2011) Factors Affecting Police Officers' Acceptance of GIS Technologies: A Study of the Turkish National Police. PhD Thesis, University of North Texas, Denton.

[49] Buchanan, D.A. and Huczynski, A.A. (2010) Organisational Behaviour. 7th Edition, Financial Times Prentice Hall, Rotolito Lombarda.

[50] Abu-Al-Aish, A. and Love, S. (2013) Factors Influencing Students' Acceptance of M-Learning: An Investigation in Higher Education. The International Review of Research in Open and Distance Learning, 14, 82-107.

[51] Kim, D. and Ammeter, T. (2014) Predicting Personal Information System Adoption Using Integrated Diffusion Model. Information and Management, 51, 451-464. http://dx.doi.org/10.1016/j.im.2014.02.011

[52] Oliveira, T., Thomas, M. and Espadanal, M. (2014) Assessing the Determinants of Cloud Computing Adoption: An 
Analysis of the Manufacturing and Services Sectors. Information and Management, 51, 497-510. http://dx.doi.org/10.1016/j.im.2014.03.006

[53] IRM (2014) About Risk Management. The Institute of Risk Management. http://www.theirm.org/about/risk-management/

[54] Payne, A., and Frow, P. (2005) A Strategic Framework for Customer Relationship Management. Journal of Marketing, 69, 167-176. http://dx.doi.org/10.1509/jmkg.2005.69.4.167

[55] Alharbi, S. and Drew, S. (2014) Using the Technology Acceptance Model in Understanding Academics' Behavioural Intention to Use Learning Management Systems. International Journal of Advanced Computer Science and Applications, 5, 143-155. http://dx.doi.org/10.14569/IJACSA.2014.050120

[56] Phichitchaisopa, N. and Naenna, T. (2013) Factors Affecting the Adoption of Healthcare Information Technology. EXCLI Journal, 12, 413-436.

[57] DeVellis, R. (2003) Scale Development: Theory and Applications. Sage Publications, Thousand Oaks.

[58] Gliem J.A. and Gliem R.R. (2003) Calculating, Interpreting, and Reporting Cronbach's Alpha Reliability Coefficient for Likert-Type Scales. 2003 Midwest Research to Practice Conference in Adult, Continuing, and Community Education, Columbus, 82-88.

[59] Hair, J.R., Anderson, R., Tatham, R.L. and Black, W. (1998) Multivariate Data Analysis. 5th Edition, Prentice-Hall International, Upper Saddle River.

[60] Kim, S. and Garrison, G. (2009) Investigating Mobile Wireless Technology Adoption: An Extension of the Technology Acceptance Model. Information Systems Frontier, 11, 323-333. http://dx.doi.org/10.1007/s10796-008-9073-8

[61] Quazi, A. and Talukder, M. (2011) Demographic Determinants of Adoption of Technological Innovation. Journal of Computer Information Systems, 52, 38-46.

[62] Talukder, M., Quazi, A. and Keating, B. (2014) Virtual Systems in Australia: A Study of Individual Users' Commitments and Usage. Journal of Internet Commerce, 13, 1-21. http://dx.doi.org/10.1080/15332861.2014.910730

[63] Talukder, M., Quazi, A. and Sathye, M. (2014) Mobile Phone Banking Usage Behavior: An Australian Perspective. Australasian Accounting, Business and Finance Journal, 8, 83-104.

[64] Kwok, S. and Gao, S. (2005) Attitude towards Knowledge Sharing Behaviour. Journal of Computer Information Systems, 46, 45-51.

[65] Owl \& Mouse (1998-2015) Owl and Mouse Educational Software. USA, Viewed 6 June 2016. http://www.yourchildlearns.com/about-us.html

[66] Talukder, M. and Quazi, A. (2011) The Impact of Social Influence on Individuals' Adoption of Innovation. Journal of Organizational Computing and Electronic Commerce, 21, 111-135. http://dx.doi.org/10.1080/10919392.2011.564483

\section{Submit or recommend next manuscript to SCIRP and we will provide best service for you:}

Accepting pre-submission inquiries through Email, Facebook, Linkedin, Twitter, etc

A wide selection of journals (inclusive of 9 subjects, more than 200 journals)

Providing a 24-hour high-quality service

User-friendly online submission system

Fair and swift peer-review system

Efficient typesetting and proofreading procedure

Display of the result of downloads and visits, as well as the number of cited articles

Maximum dissemination of your research work

Submit your manuscript at: http://papersubmission.scirp.org/ 